\title{
Effects of egg weight on hatchability, chick hatch-weight and subsequent productivity of indigenous Venda chickens in Polokwane, South Africa
}

\author{
J.W. Ng'ambi", M.W. Thamaga, D. Norris, M. Mabelebele \& O.J. Alabi \\ Department of Agricultural Economics and Animal production, University of Limpopo, \\ P/Bag X 1106, Sovenga 0727, South Africa.
}

(Received 13 October 2012; Accepted 18 February 2013; First published online 5 August 2013)

Copyright resides with the authors in terms of the Creative Commons Attribution 2.5 South African Licence. See:

http://creativecommons.org/licenses/by/2.5/za/Condition of use: The user may copy, distribute, transmit and adapt the work, but must recognise the authors and the South African Journal of Animal Science

\begin{abstract}
A study was conducted to determine the effect of egg weight on hatchability, chick hatch-weight, mortality and subsequent productivity of indigenous Venda chickens. Three hundred and sixty indigenous Venda chicken eggs were collected for a period of a week and selection was done based on the weight of the eggs. A complete randomized design was used, with four treatment weights, each with 90 eggs. The four treatment weights were as follows: below $49 \mathrm{~g}$, between 50 and $59 \mathrm{~g}$, between 60 and $69 \mathrm{~g}$, and above $70 \mathrm{~g}$. Egg weight was positively and strongly correlated with egg hatchability $\left(r^{2}=0.727\right)$ and chick hatch-weight $\left(r^{2}=0.953\right)$. Heavier-sized eggs hatched chicks had higher mortality rates. Growth rate and live weight of the chickens were optimized at different egg weights of $56\left(r^{2}=0.657\right)$ and $60\left(r^{2}=0.870\right)$ g, respectively, for chickens aged 1 to 7 weeks, and egg weights of $61 \mathrm{~g}\left(\mathrm{r}^{2}=0.514\right)$ and $60 \mathrm{~g}\left(\mathrm{r}^{2}=0.948\right)$, respectively, for chickens aged 8 to 13 weeks. It is concluded that indigenous Venda chicken egg weight affects hatchability, hatch-weight, mortality and subsequent productivity of the chickens. It is concluded that production variables were optimized at different egg weights. This means that the selection of eggs for incubation will depend on the parameter in question.
\end{abstract}

Keywords: Venda chickens, egg weight for optimal productivity, growth, mortality

\#Corresponding author: jones.ngambi@ul.ac.za

\section{Introduction}

Indigenous chickens are widely distributed in rural areas of Southern Africa and the world as a whole. They are nutritionally, economically, and culturally very important to rural households (King' ori et al., 2007; Mtileni et al., 2010). Indigenous Venda chickens are very common in rural areas of Southern Africa. However, productivity of these chickens is generally low and mortality is high, implying that appropriate genetic, nutritional and management interventions are needed to realize their optimal production potential (Okitoi et al., 2006; Mbajiorgu et al., 2011). Some work on improving productivity of Venda chickens through genetic and nutritional strategies has been done at the University of Limpopo (Mbajiorgu et al., 2011; Adesola et al., 2012). The influence of egg weight on hatchability, chick hatch-weight and subsequent growth rate and mortality of these chickens is of practical interest to Venda chicken farmers. However, there is evidence that egg weight affects subsequent productivity of layer and broiler chickens (Alders \& Spradbrow, 2001; Swatson et al., 2001; Rashid et al., 2005; King’ori et al., 2007). Alabi et al. (2012a) reported that hatchability and chick hatch-weight were higher in larger Venda chicken eggs. However, the effect of egg weight on productivity of the progenies was not determined. Alabi et al. (2012b), also reported that hatchability and post-hatch performance of Potchefstroom Koekoek chickens were higher in larger eggs. There is, thus, lack of information on the effect of egg weight on subsequent performance of indigenous Venda chickens. Therefore, the objective of this study was to determine the effect of egg weight on hatchability, chick hatch-weight and subsequent productivity of indigenous Venda chickens. 


\section{Materials and Methods}

This study was conducted at the University of Limpopo in South Africa. The first part of the study determined the effect of egg weight on hatchability and chick hatch-weight. A total of 360 indigenous Venda chicken eggs were classified into four treatments on the basis of their weight as follows: $\mathrm{W}_{<49 \mathrm{~g}}$ (less than 49 g eggs), $W_{50-59 g}\left(50\right.$ - 59 g eggs), $W_{60-69 g}\left(60\right.$ - 69 g eggs) and $W_{>70 g}$ (above 70 g eggs). The eggs came from Venda hens kept indoors at the University of Limpopo Experimental Farm. A completely randomized design was used, having four treatments and five replicates, resulting in a total of 20 units of 18 eggs each. The eggs were incubated and hatched at the University of Limpopo Hatchery Unit. The second part of the study determined the effect of chick weight on feed intake, growth rate, live weight and mortality of the hatched Venda chicks aged 1 - 7 weeks. Hatched chicks were reared on a similar grower diet and housed in enclosed pens, but kept separately according to the initial treatment of the eggs. Feed and water were offered $a d$ libitum. The grower diet offered to the chicks contained $880 \mathrm{~g} \mathrm{DM} / \mathrm{kg}, 16.8 \mathrm{MJ}$ energy $/ \mathrm{kg} \mathrm{DM}, 200 \mathrm{~g}$ crude protein $/ \mathrm{kg} \mathrm{DM}, 11.5 \mathrm{~g}$ lysine $/ \mathrm{kg} \mathrm{DM}$, and $25 \mathrm{~g}$ fat $/ \mathrm{kg} \mathrm{DM}$. The third part of the study determined the effect of chick weight on feed intake, feed conversion ratio, growth rate, live weight and mortality of the hatched female Venda chickens aged between 8 and 13 weeks. Sixty female Venda chickens, aged 7 weeks, weighing $464 \pm 2 \mathrm{~g}$, were used for this part of the study. The chickens were fed the same grower diet used in the second part of the study. The experiment was terminated when the chickens were 13 weeks old, at which age Venda chickens are slaughtered for meat at the University of Limpopo. A complete randomized design with four treatments, according to the initial egg weight treatments, was used. Routine vaccinations and health management practices were followed for all the birds.

The hatchability percentage and hatchling weight were determined within 24 hours after hatching. Feed intake, initial live weight and feed conversion ratio were determined. Mortalities were recorded as they occurred per pen. Effect of egg weight on hatchability, chick hatch-weight, feed intake, growth rate and mortality rate of the chickens were analysed using the General Linear Model procedure of the Statistical Analysis System (SAS, 2008). The means were separated using Duncan's multiple-range test procedures (Duncan, 1955). The responses in intake, feed conversion ratio, growth rate and live weight to egg weight were modelled using the following quadratic equation:

$$
\mathrm{Y}=\mathrm{a}+\mathrm{b}_{1} \mathrm{x}+\mathrm{b}_{2} \mathrm{x}^{2}
$$

where $\mathrm{Y}=$ optimum feed intake, feed conversion ratio, growth rate, live weight and mortality rate; $\mathrm{a}=$ intercept; $\mathrm{b}=$ coefficients of quadratic equation; $\mathrm{x}=$ egg weight and $-\mathrm{b}_{1} / 2 \mathrm{~b}_{2}=\mathrm{x}$ value for optimum response. The quadratic model was fitted to the experimental data by means of NLIN procedure of SAS (SAS, 2008). The quadratic model was used, because it gave the best fit.

\section{Results and Discussion}

Results of the effect of egg weight on hatchability and chick hatch-weight of indigenous Venda chickens are presented in Table 1 . Heavier eggs had higher $(P<0.05)$ hatchability values. Similarly, heavier eggs hatched heavier $(P<0.05)$ chicks. These findings are similar to those of Alabi et al. $(2012 \mathrm{a}$; b) in Venda and Potchefstroom Koekoek chickens, respectively. Constantini \& Panella (1984), who found similar results in broiler chickens, concluded that the higher chick hatch-weights are result of higher nutrient content in larger eggs. However, Gonzalez et al. (1999) and Abiola et al. (2008) found that broiler chicken eggs of medium weight were more suitable for setting in order to obtain higher hatchability.

In the present study, egg weight was positively and strongly correlated $\left(r^{2}=0.729\right)$ with egg hatchability (Table 2). Farooq et al. (2001) and Narkhede et al. (1981) found negative correlations between egg weight and hatchability in crossbred chickens. Thus, in their studies, heavier eggs resulted in lower hatchability. In the present study, egg weight was positively and strongly correlated $\left(\mathrm{r}^{2}=0.953\right)$ with chick hatch-weight. Narkhede et al. (1981) reported a strong and positive correlation $\left(r^{2}=0.93\right)$ between egg weight and chick hatch-weight in crossbred chickens (Rhode Island Red X White Leghorn). Tona et al. (2002) found similar findings in broiler chickens. However, Asuquo \& Okon (1993) observed that egg size within the intermediate weight range of 45 to $56 \mathrm{~g}$ hatched heavier chicks than smaller or larger eggs. No biological reasons were suggested for such an observation. 
Table 1 Effect of egg weight (g/egg) on egg hatchability (\%) and chick hatch-weight (g/chick) of indigenous Venda chickens

\begin{tabular}{|c|c|c|c|c|c|}
\hline \multirow[b]{2}{*}{ Variable } & \multicolumn{4}{|c|}{ Treatment } & \multirow{2}{*}{ SE } \\
\hline & $W_{<49 g}$ & $\mathrm{~W}_{50-59 \mathrm{~g}}$ & $\mathrm{~W}_{60-69 \mathrm{~g}}$ & $\mathrm{~W}_{>70 \mathrm{~g}}$ & \\
\hline Hatchability & $28.1^{\mathrm{d}}$ & $45.5^{\mathrm{c}}$ & $48.3^{\mathrm{b}}$ & $73.9^{\mathrm{a}}$ & 0.01 \\
\hline Hatch-weight & $29.0^{\mathrm{d}}$ & $31.0^{c}$ & $32.0^{\mathrm{b}}$ & $33.0^{\mathrm{a}}$ & 0.02 \\
\hline
\end{tabular}

Table 2 Relationships between indigenous Venda chicken egg weight (g/egg) and egg hatchability (\%) and chick hatch-weight (g/chick)

\begin{tabular}{lcc}
\hline Variable & Equation & $\mathrm{r}^{2}$ \\
\hline Hatchability & $\mathrm{Y}=-52.239+1.639 \mathrm{X}$ & 0.729 \\
Hatch-weight & $\mathrm{Y}=20.790+0.169 \mathrm{X}$ & 0.953 \\
\hline $\mathrm{r}^{2}$ correlation coefficient. & &
\end{tabular}

Table 3 Effect of indigenous Venda chicken egg weight on dry matter intake (g/bird/day), growth rate (g/bird/day), feed conversion ratio (FCR) (g DM feed/g weight gain), live weight (g/bird) and mortality between 1 - 7 weeks of age

\begin{tabular}{lccccc}
\hline \multirow{2}{*}{ Variable } & \multicolumn{4}{c}{ Treatments } & \multirow{2}{*}{$\mathrm{SE}$} \\
\cline { 2 - 5 } & $\mathrm{W}_{<49 \mathrm{~g}}$ & $\mathrm{~W}_{50-59 \mathrm{~g}}$ & $\mathrm{~W}_{60-69 \mathrm{~g}}$ & $\mathrm{~W}_{>70 \mathrm{~g}}$ & \\
\hline & & & & \\
Intake & $57.4^{\mathrm{a}}$ & $49.0^{\mathrm{b}}$ & $48.0^{\mathrm{b}}$ & $34.0^{\mathrm{c}}$ & 1.58 \\
Growth rate & $6.6^{\mathrm{ab}}$ & $6.7^{\mathrm{a}}$ & $6.3^{\mathrm{b}}$ & $6.5^{\mathrm{ab}}$ & 0.11 \\
Feed conversion ratio & $8.7^{\mathrm{a}}$ & $7.3^{\mathrm{b}}$ & $7.6^{\mathrm{b}}$ & $5.2^{\mathrm{c}}$ & 0.28 \\
Live weight & $470.6^{\mathrm{b}}$ & $582.0^{\mathrm{a}}$ & $480.6^{\mathrm{b}}$ & $507.2^{\mathrm{ab}}$ & 26.02 \\
Mortality & $0.0^{\mathrm{d}}$ & $2.5^{\mathrm{c}}$ & $8.9^{\mathrm{a}}$ & $7.7^{\mathrm{ab}}$ & 2.47
\end{tabular}

$\overline{\mathrm{a}, \mathrm{b}, \mathrm{c}, \mathrm{d}}$ Means with different superscripts within a row are significantly different $(P<0.05)$.

SE: standard error.

Results of the effect of egg weight on feed intake, growth rate, feed conversion ratio, live weight and mortality of indigenous Venda chickens aged 1 to 7 weeks are presented in Table 3. Chick weight had a significant $(P<0.05)$ effect on feed intake, growth rate, live weight and mortality of the chickens. Chickens hatched from smaller eggs had higher $(P<0.05)$ intakes than those hatched from heavier eggs. Petek et al. (2003) found similar results in quails. However, Vieira \& Moran (1998) found no differences in intake due to differences in broiler chicken egg weights. In the present study, chicks hatched from heavier eggs had better (lower) $(P<0.05)$ feed conversion ratios (Tables 3 and 4$)$. This is similar to the findings of Petek et al. (2003) in quails. However, De Witt \& Schwalbach (2004) found that feed conversion ratio was better in chicks hatched from medium New Hampshire and Rhode Island Red eggs than in those hatched from larger eggs. Venda chicks hatched from heavier eggs had higher $(P<0.05)$ mortality rates (Tables 3 and 4$)$. This is similar to the findings of Alabi et al. (2012b) in Potchefstroom Koekoek chicken eggs. Growth rate and live 
weight of Venda chickens aged between 1 and 7 weeks were optimized at different egg weights of 56 and 60 g, respectively (Table 5).

Table 4 Relationships between indigenous Venda chicken egg weight (g/egg) and feed intake (g/kg), feed conversion ratio (g/DM feed/g weight gain) and mortality of indigenous Venda chickens aged 1 - 7 weeks

\begin{tabular}{lcc}
\hline Variable & Equation & $\mathrm{r}^{2}$ \\
\hline Feed intake & $\mathrm{Y}=97.668-0.819 \mathrm{X}$ & 0.691 \\
Feed conversion ratio & $\mathrm{Y}=14.209-0.113 \mathrm{X}$ & 0.584 \\
Mortality & $\mathrm{Y}=-20.960+0.417 \mathrm{X}$ & 0.943 \\
\hline $\mathrm{r}^{2}$ : correlation coefficient. & &
\end{tabular}

Table 5 Venda chicken egg weight (g/egg) for subsequent optimal growth rate (g/bird/day) and live weight (g/bird) of the chicks between 1 and 7 weeks of age

\begin{tabular}{lcccr}
\hline Variable & Equation & $\mathrm{r}^{2}$ & Egg weight & Optimal Y level \\
\hline Growth rate & $\mathrm{Y}=1.681+0.178 \mathrm{X}-0.002 \mathrm{X}^{2}$ & 0.657 & 56 & 6.7 \\
Live weight & $\mathrm{Y}=-2644.390+107.605 \mathrm{X}-.898 \mathrm{X}^{2}$ & 0.870 & 60 & 579.1 \\
\hline
\end{tabular}

$\mathrm{r}^{2}$ : regression coefficient; X: egg weight.

Egg weight did not affect $(P>0.05)$ subsequent dry matter intake, growth rate, feed conversion ratio, metabolisable energy, nitrogen retention and live weight of female indigenous Venda chickens between 8 and 13 weeks old (Table 6). Vieira \& Moran (1998) observed similar results in broiler chickens. However, Petek et al. (2003) found that older broiler chickens hatched from heavier eggs had higher growth rates. These authors explained their results in terms of higher intakes.

Table 6 Effect of Venda chicken egg weight on subsequent intake (g/bird/day), growth rate (g/bird/day), feed conversion ratio (FCR) (g DM feed g/weight gain), metabolisable energy (ME) (MJ/kg DM), nitrogen retention (g/bird/day) and live weight (g/bird aged 13 weeks) of female chickens between 8 and 13 weeks of age

\begin{tabular}{|c|c|c|c|c|c|}
\hline \multirow{2}{*}{ Variable } & \multicolumn{4}{|c|}{ Treatment } & \multirow{2}{*}{ SE } \\
\hline & $W_{<49 g}$ & $\mathrm{~W}_{50-59 \mathrm{~g}}$ & $\mathrm{~W}_{60-69 \mathrm{~g}}$ & $\mathrm{~W}_{>70 \mathrm{~g}}$ & \\
\hline Intake & 93 & 98 & 106 & 94 & 5.56 \\
\hline Growth rate & 1.8 & 2.1 & 1.8 & 2.0 & 0.12 \\
\hline Feed conversion ratio & 5.0 & 4.9 & 6.7 & 4.8 & 0.68 \\
\hline Metabolisable energy & 11.8 & 12.0 & 11.9 & 11.7 & 0.71 \\
\hline $\mathrm{N}$ retention & 0.59 & 0.63 & 0.78 & 0.41 & 0.251 \\
\hline Live weight & 1085 & 1192 & 1144 & 1102 & 55.45 \\
\hline
\end{tabular}

SE: standard error. 


\section{Conclusion}

It is concluded that indigenous Venda chicken egg weight affected hatchability, hatch-weight, mortality and subsequent productivity of the chickens. However, these variables were optimized at different egg weights. This has implications on selection of eggs for incubation.

\section{Acknowledgements}

The authors would like to acknowledge the National Research Foundation (Incentive Funding for Rated Researchers) and VLIR for their financial support.

\section{References}

Abiola, S.S., Meshioye, O.O., Yerinde, B.O. \& Bamgbose, M.A., 2008. Effect of egg size on hatchability of broiler chicks. Nigerian Agric. J. 57, 83-86.

Adesola, A.A., Ng'ambi, J.W. \& Norris, D., 2012. Effect of ascorbic acid supplementation level to the diets of indigenous Venda hens on egg production, hatchability and subsequent productivity of chicks. Afr. J. Biotechnol. 11, 12606-12611.

Alabi, O.J., Ng'ambi, J.W. \& Norris, D., 2012a. Effect of egg weight on physical egg parameters and hatchability of indigenous Venda chickens. Asian J. Anim. Vet. Adv. 7, 166-172.

Alabi, O.J., Ng'ambi, J.W., Norris, D. \& Mabelebele, M., 2012b. Effect of egg weight on hatchability and subsequent performance of Potchefstroom Koekoek. Asian J. Anim. Vet. Adv. 7, 718-725.

Alders, R.G. \& Spradbrow. P.B., 2001 Controlling Newcastle disease in village chickens: A Field Manual. ACIAR Monograph No. 82, pp. 112-116.

Asuquo, B.O. \& Okon, B., 1993. Effects of age in lay and egg size on fertility and hatchability of chicken eggs. Nigerian J. Anim. Prod.20, 122-124.

Constantini, F. \& Panella, F., 1984. Correlations between egg weight chick weight and broilers performance. Anim. Breed. Abstr. 51, 35-40.

De Witt, F. \& Schwalbach, L.M.J., 2004. The effect of egg weight on the hatchability and growth performance of New Hampshire and Rhode Island Red chicks. S. Afr. J. Anim. Sci. 34 (Suppl. 2), 62-64.

Duncan, D.B., 1955. Multiple ranges and multiple F test. Biometrics 11, 1-42.

Farooq, M., Durrani F.R., Aleem M., Chand, N. \& Muquarrab, A.K., 2001. Egg traits and hatching performance of Desi, Fayumi and Rhode Island Red chickens. Pakistan J. Biol. Sci. 4, 909-911.

Gonzalez, A., Satterlee, D.G., Moharer, F. \& Cadd, G.G., 1999. Factors affecting ostrich egg hatchability. Poult. Sci. 78, 1257-1262.

King’ori, A.M., Tuitoek, J.K., Muiruri, H.K. \& Wachira, A.M., 2003. Protein requirements of growing indigenous chickens during the 14-21 weeks growing period. S. Afr. J. Anim. Sci. 33, 78-81.

Mbajiorgu, C.A., Ng'ambi, J.W. \& Norris, D., 2011. Effect of varying dietary energy to protein ratio level on growth and productivity of indigenous Venda chickens. Asian J. Anim. Vet. Adv. 6, 344-352.

Mtileni, B.J., Muchadeyi, F.C., Maiwashe, A., Phitsane, P.M., Halimani, T.E., Chimonyo, M. \& Dzama, K., 2010. Characterisation of production systems for indigenous chicken genetic resources in South Africa. Appl. Anim. Husb. Rural Dev. 2, 18-22.

Narkhede, J.S., Thatte, V.R., Singh, S.N., Kinhikar, V.N. \& Deshmukh, S.N., 1981. Study on fertility, hatchability and relationship between egg weight and hatch weight. Poult. Sci. 16, 421-424.

Okitoi, L.O., Udo, H.M.J., Mukisira, E.A., de Jong, R. \& Kwakkel, R.P., 2006. Evaluation of low - Input interventions for improved productivity of indigenous chickens in Western Kenya. Agric. Trop. Subtrop. 39, 178-181.

Petek, M., Baspinar, H. \& Ogan, M., 2003. Effects of egg weight and length of storage on hatchability and subsequent growth performance of quail. S. Afr. J. Anim. Sci. 33, 242-247.

Rashid, M.M., Islam, M.N., Roy, B.C., Jakobsen, K. \& Lauridsen, C., 2005. Nutrient concentrations of crop and gizzard contents of indigenous scavenging chickens under rural conditions of Bangladesh. Livest. Res. Rural Dev. 17, 122-132.

SAS, 2008. Statistical Analysis Systems User's Guide: Statistics, $9^{\text {th }}$ edition. SAS Institute, Inc. Raleigh, North Carolina, USA. 
Swatson, H.K., Nsahlai, I.V. \& Bycbwa, B., 2001. The status of smallholder poultry production in the Alfred district of KwaZulu-Natal, South Africa: Priorities for intervention. Department of Animal and Poultry Science, University of Natal, Pietermaritzburg, South Africa.

Tona, K., Bamelis, F., De Ketelaere, B., Bruggeman, V. \& Decuypere, E., 2002. Effect of inducing moulting on albumen quality, hatchability and chick body weight from broiler breeders. Poult. Sci. 81,327-332.

Vieira, S.L. \& Moran, E.T., 1998. Effects of extremes in egg weight from broiler breeder flocks of diverse strain crosses on live performance, carcass quality, and further processing of yields. Poult. Sci. 75, 69-73. 